\title{
IN THE AFTERMATH OF SALAMIS: THE REVOLT OF POTIDAEA
}

\begin{abstract}
Following the Persian defeat at Salamis and Xerxes' departure from Europe, the Persian naval power in the Aegean Sea sharply declined. In this geopolitical context, Herodotus reports the outbreak of the revolt of Potidaea and the nearby communities in Pallene, the westernmost peninsula of Chalcidice, against the Persians. The army detachment sent to quash the insurrection was repulsed, supposedly thanks to a natural disaster, caused by divine intervention, which decimated the Achaemenid troops. This defeat marks the first and only permanently successful secessionist revolt against the Achaemenid Empire. However, the largely anecdotal account of Herodotus still leaves a few questions unanswered: Why did Potidaea revolt? Why was its example not imitated by the neighboring peoples? How can the Persian defeat be rationally explained? The present study aims at answering the aforementioned questions, by critically examining the account of Herodotus and by taking into consideration the geographical particularities of the peninsula of Pallene. The case of Potidaea is then compared to the position of other Aegean communities under Persian domination, in an effort to understand the challenges the Achaemenid authorities faced in the turbulent period between the battles of Salamis and Mycale.
\end{abstract}

\section{Herodotus' Testimony}

As mentioned above, the Potidaean revolt of 480/479 B.C. against the Persians is, despite its geographically modest dimensions, a unique event in Achaemenid history: It is the only known instance of a successful separatist revolt that resulted into the definitive and irreversible secession of a region that had formerly recognized the authority of the Persian King. Even Egypt, which had managed to overthrow the Persian authorities in the beginning of Artaxerxes II's reign, was eventually reconquered by Artaxerxes III. ${ }^{1}$ However, the Potidaean revolt, despite its unique characteristics, as well as the fact that it makes part of one of the most studied events of ancient history, the invasion of Xerxes against the Greek city states, is only briefly examined

${ }^{1}$ The account of Diodorus (XVI, 46, $4-51,3$ ), albeit not flawless, is the most important narrative source for the Persian reconquest of Egypt. 
in modern historiography, ${ }^{2}$ which focuses its attention primarily on the principal theater of operations between the Persians and the southern Greek city-states.

In any case, the work of Herodotus ${ }^{3}$ is essentially the only available source about the revolt, ${ }^{4}$ as the other two authors that mention one specific episode of the conflict, Polyaenus ${ }^{5}$ and Aeneas the Tactician, ${ }^{6}$ simply repeat the relevant paragraph from Herodotus' Histories. Herodotus places his narrative of the uprising in the immediate aftermath of Xerxes' departure from Greece, his destination being Sardis, the capital of the Lydian satrapy and the main imperial headquarters in the northwestern extremity of the Achaemenid Empire. According to Herodotus, Xerxes reached the soil of Asia, after having crossed Macedonia and Thrace, escorted by a force of $60.000 \mathrm{men}^{7}$ under the leadership of Artabazus. ${ }^{8}$ Then, the author of the Histories proceeds to describe the activities of the Persian commander, once he completed his primary duty of accompanying the Great King to the Hellespont. As large military operations had ceased in the south, due to the arrival of the winter season (the main Persian army was wintering under Mardonius in Thessaly), Artabazus decided to take advantage of the lull in the main front, in order to reduce the city of Potidaea into utter slavery. ${ }^{9}$

${ }^{2}$ For some indicative examples, see Macan 1908: 553-558, Munro 1953: 316, Burn 1962: 496-499, Alexander 1963: 31-34, Hignett 1963: 270-271, Hammond 1967a: 245, Balcer 1984: 267, Dandamaev 1989: 214, Lazenby 1993: 206-207, Briant 1996: 547, Green 1996: 217-219 and Vasilev 2015: 197.

${ }^{3}$ Herodotus, VIII, 126-129.

${ }^{4}$ That being said, an allusion to the revolt is made by Aristotle (Rhetoric, II, 22, 7), who mentions that the Potidaeans had fought, together with the Athenians, with distinction against the "barbarian" (i.e. the Persians).

${ }^{5}$ Polyaenus, VII, 33, 1.

${ }^{6}$ Aeneas the Tactician, XXXI, 25-27.

${ }^{7}$ Herodotus (VIII, 126, 1) claims that 60.000 soldiers escorted Xerxes to Asia. Without doubt, the size of Xerxes' escort was not negligible, but the cited figure is not at all believable. Such a large escort not only would have fatally undermined Mardonius' military power in Thessaly (in fact, 60.000 may have been a greater figure than the total number of Xerxes' army), but it would also negatively affect their mission, since it would decrease the rapidity and flexibility of Xerxes' departure, who, according to Herodotus (VIII, 115, 1), managed to cross the Balkans in just 45 days.

${ }^{8}$ Artabazus was the son of Pharnaces, an Iranian noble positioned very highly in the social and bureaucratic hierarchy of the Achaemenid Empire. Artabazus initially commanded the military contingents from Parthia and Chorasmia (Herodotus, VII, 66, 2). His administrative career continued well after Xerxes' invasion, as he was eventually appointed satrap of Hellespontine Phrygia (Thucydides, I, 129, 1), thus succeeding in establishing a satrapal dynasty that would manage the affairs of Hellespontine Phrygia, until the reign of Artaxerxes III (359/358-338 B.C.). For a prosopographical note on Artabazus and an examination of his career and nomination as satrap, see respectively Balcer 1993: 85 and Klein 2015: 117-124.

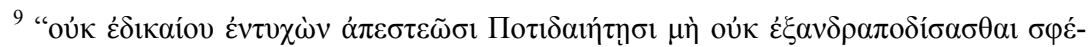
a५.”, Herodotus, VIII, 126, 2. 
As Herodotus explains, the Potidaeans and the other communities of Pallene had risen in revolt ${ }^{10}$ against the Persians, once Xerxes and the imperial fleet left the region.

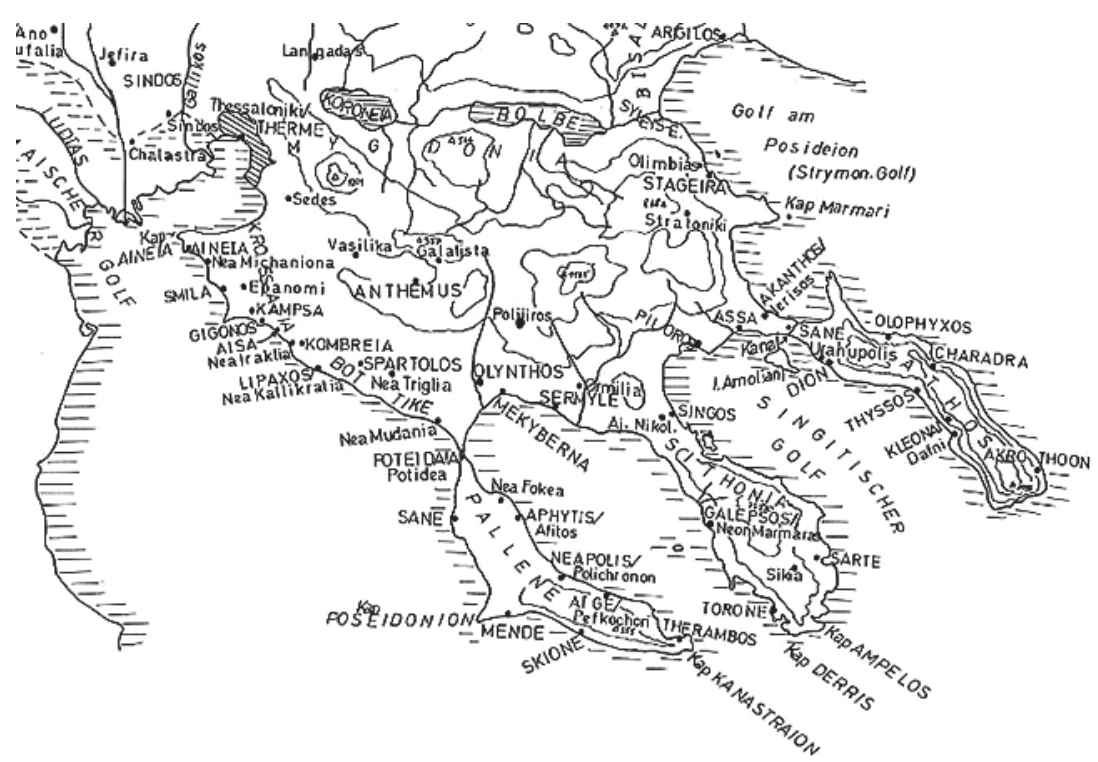

Fig. 1: Map of Chalcidice (Müller 1987: p. 127)

Artabazus therefore besieged Potidaea, but he also attacked the city of Olynthus, inhabited by the tribe of the Bottiaei ${ }^{11}$ and located in the north of Potidaea, which he also suspected of seditious intentions. Having captured Olynthus, Artabazus placed it under the administration of a certain Critoboulus of Torone ${ }^{12}$ and repopulated it with the natives of Chalcidice. As for the captive inhabitants of Olynthus, they were massacred on the shores of an anonymous lake. ${ }^{13}$ Having disposed

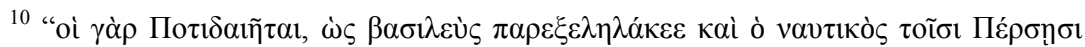

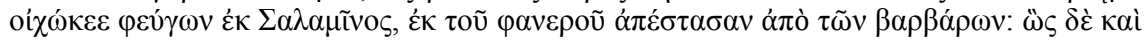

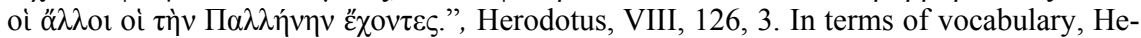
rodotus consistently employs (VIII, $126,2-3 ; 127)$ the derivatives $(\dot{\alpha} \pi \varepsilon \sigma \tau \varepsilon \tilde{\omega} \sigma \mathrm{l}, \dot{\alpha} \pi \dot{\varepsilon} \sigma \tau \alpha-$

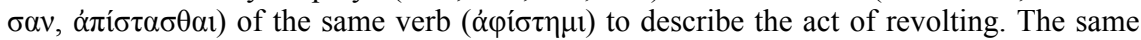
word is also used to refer to several other cases of rebellion that are documented in the Histories [e.g. $\dot{\alpha} \pi \dot{\varepsilon} \sigma \tau \eta \sigma \alpha v$ for both the Median uprising against Darius I $(\mathrm{I}, 130,2)$ and the Egyptian revolution against the pharaoh Apries (IV, 159, 6)].

${ }^{11}$ Herodotus adds that the Bottiaei used to live near the Thermaic Gulf, but they were driven away by the Macedonians. For a concise summary of the presence of the Bottiaei in the historical record, see Psoma 1999: 46-54.

${ }^{12}$ Torone was a Chalcidicean city, situated in the peninsula of Sithonia, to the east of the rebellious peninsula of Pallene. The Toronean Gulf, which separates Sithonia and Pallene, takes its name from the town of Torone.

13 As Herodotus never reveals the lake's name, its identity remains obscure. However, in an area which generally features neither valleys nor rivers large enough to 
of Olynthus, Artabazus now concentrated his efforts on overcoming the resistance of Potidaea, which was not only the main city of Pallene, but, situated on a narrow isthmus, also controlled the access to the rest of the peninsula. Moreover, the garrison of Potidaea had been reinforced by detachments sent by the rest of Pallene's rebellious communities. The commander of one of them, Timoxenus of Scione, was secretly approached by the Persians. The besiegers contacted Timoxenus, by tying the conspiratorial messages to the tips of the arrows, which they then fired inside the city. Unfortunately for the Persians, their clandestine communication was accidentally intercepted by the Potidaeans, who however opted not to condemn Timoxenus, supposedly for the sake of not labeling the inhabitants of Scione as traitors. However, although Timoxenus remained unpunished, the discovery of the secret negotiations put an end to any Persian plan of sabotaging the Potidaean resistance from within.

Subsequently, while the siege was progressing, a great ebb occurred, of which the Persians took advantage, in order to circumvent the defenses of the city, by attacking across the now dried seafloor. The Persian forces had already crossed almost half the distance, until the waters returned in a great tide. As a result of the disaster, several soldiers were either drowned or killed by the Potidaeans, embarked on boats and determined to eliminate any Persian who tried to swim back to safety. Having witnessed the failure of his manœuvre, Artabazus promptly abandoned the siege and united his army with that of Mardonius, whose troops were resting in preparation for the upcoming spring campaign. Finally, Herodotus closes his narration, by citing the explanation provided by the Potidaeans for the seemingly miraculous tsuna$\mathrm{mi}$, an explanation that he himself willingly endorses. ${ }^{14}$ According to the Potidaeans, the Persians were punished for their sacrilegious acti-

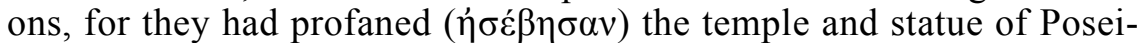
don, situated in the suburbs of Potidaea, which were presumably left unprotected by the walls and were thus vulnerable to Persian raids.

Overall, the author of the Histories dedicates four full paragraphs to the Potidaean affair, although he does not narrate it as exten-

allow the creation of significant bodies of water, there are only two possible candidates, lake Coronea and lake Bolbe. Nowadays, both lie near the border of the modern prefectures of Chalcidice and Thessalonica, in a small distance from the ancient ruins of Olynthus. Of course, the local landscape has visibly changed during the last 2.500 years, as varying river flow patterns, erosion and irrigation have been gradually transforming the shape and the size of the lakes, but there is little doubt that Coronea and Bolbe were the principal bodies of water in the vicinity of Olynthus even before the $5^{\text {th }}$ century B.C.. That being said, Macan suggests that the massacre took place near lake Bolyce (Macan 1908: 555), generally identified with the marshes of Agios Mamas, to the north of Potidaea (Dimitsas 1870: 162 and Isambert 1873: 729). However, lake Bolyce does not actually exist. Its name has been accidentally invented by a $16^{\text {th }}$ century copyist, who had misread the name of lake Bolbe (Manoledakis 2015: 144-146).

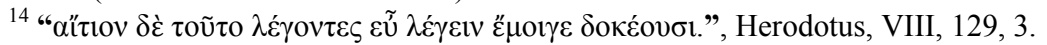


sively as the most famous episodes of Xerxes' invasion. Herodotus mentions several incidents, like the assault against Olynthus and the terrible fate of its citizenry, as well as the controversial affair of Timoxenus, but his account is clearly dominated by the tsunami, which also serves as the appropriate conclusion for the small digression about the military developments in Chalcidice and which probably also explains why Herodotus described the rebellion in a relatively detailed manner in the first place. By accepting the role of the divine intervention, Herodotus is given a chance to further establish a common pattern in his work: Blasphemous actions provoke the fury of the gods, resulting into the appropriate punishment of the offender. ${ }^{15}$ In conclusion, although Herodotus' account is relatively detailed, it still poses two major obstacles for its comprehension: The preferred interpretation about the failure of the Persian operations is purely moralistic and defies natural laws, while there is also no explanation about why Pallene rose against the Persians, despite the rest of Thrace and Macedonia remaining loyal.

\section{The Origins of the Revolt}

To detect the causes of the conflict, the circumstances of Potidaea's integration to the Persian Empire must be firstly examined. The first advance of Persian troops in the region of the southern Balkans occurred during Megabazus' expedition in southern Thrace and Macedonia, in the aftermath of Darius' campaign against the Scythians. ${ }^{16}$ Herodotus reports the entry of the Argead kingdom to the Persian sphere of influence, ${ }^{17}$ but no reference to Chalcidice, in general, or Pallene, in particular, is made. Similarly, neither Chalcidice nor Pallene are mentioned during Mardonius' campaign in Thrace, following the repression of the Ionian Revolt (499-494 B.C.). Herodotus only reports ${ }^{18}$ that the Persian fleet was wrecked by a violent storm, during its attempt to navigate around Athos, the third peninsula of Chalcidice, to the east of Sithonia. In the meantime, Mardonius managed to subjuga-

${ }^{15}$ For the divine and causative nature of vengeance in Herodotus, see De Romilly 1971: 315-317.

${ }^{16}$ The Scythian campaign of Darius I is generally dated in 513 B.C. (see, among others, Olmstead 1948: 141, Frye 1962: 117, Shahbazi 1982: 232-235 and Briant 1996: 154). For a condensed summary of the issues surrounding the dating of the Scythian campaign, see Mitchell 1966: 103 and Gardiner-Garden 1987: 326-330. This estimation is founded upon the information provided by Tabula Capitolina (IG XIV 1297). The reliability of Tabula Capitolina has however been contested, with the alternative date of 519 B.C. being proposed instead (Balcer 1972: 99-132 and Cameron 1975: 77-80), based on the argument that the Scythian expedition should be identified with the conflict between Darius and the Sacae, described in the Behistun Inscription ( $D B \S 74-75)$. This hypothesis seems however implausible (Briant 1996: 931).

\footnotetext{
${ }^{17}$ Herodotus, V, 17-21.

${ }^{18}$ Herodotus, VI, 44-45.
} 
te the Thracian tribe of the Bryges, despite suffering serious casualties in the process. Given the location of the naval disaster, as well as the fact the Bryges were the neighbors of the Macedonians, ${ }^{19}$ living in the northwest of Pallene, it can be surmised that Mardonius indeed campaigned in the environs of Chalcidice. However, Herodotus also adds that the Persian general was forced to withdraw prematurely, despite having achieved the submission of the Bryges, due to the serious casualties they had inflicted upon the Persian army, so the conquest of Pallene by Mardonius cannot be confirmed with absolute certainty.

However, there is no doubt that Chalcidice had recognized the suzerainty of Persia by the time of Xerxes' invasion, as Potidaea, together with several other towns located in Sithonia (Torone, Galepsus, Sermule, Myceberna) and Pallene (Sane, Mende, Neapolis, Aege, Therambo, Scione, Aphytis), has been attested to have sent ships and men to reinforce the Persian army. ${ }^{20}$ The aforementioned piece of information confirms that Chalcidice, even if it had been left untouched by Megabazus and Mardonius, was firmly attached to the Persian Empire, by the time the fleet and army of Xerxes reached the region. Either the local communities had already been subjects of the Great King or the appearance of the immense military forces of Xerxes ${ }^{21}$ convinced them to quickly abandon any thoughts of resistance and to promptly join the currently supreme military power of the Aegean Sea. Additionally, the remark of Herodotus about the tribute in men and matériel sent to Xerxes could also illustrate some of the factors that provoked the hostility of the Potidaeans against the Achaemenid regime.

Namely, the peoples of Pallene and Sithonia were obliged to surrender a significant portion of their manpower and fleet, whose lives and integrity would lie under constant risk, to the Persians. Even if the campaign had proven to be successful for the Great King, the fruits of victory would have solely benefited the Achaemenid Empire, without presenting any tangible advantage for Xerxes' presumably not particularly enthusiastic allies. Moreover, it is difficult to imagine that the march of the army and the passage of the fleet had a positive impact on the economy of the region. Even if the troops were exceptionally drilled and disciplined and the coffers of the army adequately filled with provisions, the insurmountable needs of thousands of men and hundreds of ships would inevitably result into a certain degree of devastation for the affected lands, as soldiers and officers forcefully demanded provisions, housing and labour, further adding fuel to the fire

${ }^{19}$ Herodotus, VII, 73.

${ }^{20}$ Herodotus, VII, 122-123, 1.

${ }^{21}$ Regardless of the obvious exaggerations of the Greek authors, who elevate the number of Xerxes' troops to millions, the Persians must have enjoyed a remarkable numerical superiority, at least during the early stages of the conflict. For an informative discussion about the size of Xerxes' army and fleet, with references to the previous bibliography, see Lazenby 1993: 90-97. 
of anti-Persian sentiments. Political tensions flaring up as a consequence of local economies getting exhausted by demands for military supplies is not unheard of in Persian history. ${ }^{22}$

Furthermore, besides confiscations and material damage, it is also safe to assume that the prosperity of the region, especially intercommunal commerce and agriculture, suffered considerably, as a result of the Persian invasion, which severely disrupted the long-established trade routes, as well as the yearly harvests. Additionally, the size of the commercial and fishing fleets of the local communities might have also declined, due to the requisitions of naval vessels and the conscription of their crews for military and transport duties. Finally, the veracity of the last potential reason depends on how long Chalcidice had accepted the Persian suzerainty. If its submission had been completed since the reign of Darius I, then Pallene and Sithonia must have also regularly contributed to the imperial and satrapal treasuries long before Xerxes' expedition. Contrary to the earlier claims of overtaxation, ${ }^{23}$ the tributary demands of Susa would not have strangled the local economies, but they definitely did not strengthen the popularity of the imperial authorities either.

Thus, it can be deduced from the above that there were quite a few reasons for the local peoples to express hostility against the Persian domination of their lands. However, since they had obediently accepted Xerxes' orders in the early stages of the expedition, the situation had apparently changed drastically since then. The decisive factor behind this shift lies in the transformation of the geopolitical context,

${ }^{22}$ The most typical example is the revolt of Sidon $(\sim 348 / 347-345$ B.C. $)$ against Artaxerxes III. Diodorus, essentially the only literary source for the rebellion, highlights (XVI, 40,6) the massive preparations of the Persians for the upcoming campaign against the Egyptian pharaoh Nectanebo II, but also mentions the frustration of the Phoenicians due to the heavy-handed and authoritarian behaviour of the Great King's officials (XVI, $41,2)$, as well as the fact that one of the first actions of the rebels was to burn the fodder collected for the needs of the Achaemenid cavalry (XVI, 41, 5). All these remarks strongly indicate that one of the reasons, perhaps even the principal one, for the outbreak of the Sidonian rebellion concerned the exorbitant requisitions ordered by the Persians for the logistical needs of the expeditionary army, at the expense of the local societies (cf. Grainger 1991: 124-125, Briant 1996: 1030, Elayi 2013: 288-289 and Wiesehöfer 2016: 101105). Secondly, a similar example of how gravely military requisitions affect the economy and the social cohesion of the local communities might be the case of Babylonia under Cambyses II. During the early years of his reign (528-526 B.C.), several cuneiform documents attest a remarkable increase of barley price and a respectively severe lack of rations for the temple workers, both of which are signs of an impending or an already present famine (Kleber 2012: 219-236). The disaster must have been largely the result of harvest failures, due to meteorological phenomena or locust swarms, but the massive military preparations of Cambyses for his campaign against Egypt have also been put forward as a possible explanation (Joannès 2021: 209-210).

${ }^{23}$ For the interpretation of the "Persian decline" as a result of the ruinous effects of over-taxation and over-exploitation imposed by the Achaemenid authorities, see Olmstead 1948: 297-299, Burn 1962: 565-567 and Harris 1971: 106. For a convincing counter-argument against that theory, see Briant 1996: 820-824. 
following the naval defeat of the Persians at Salamis and the subsequent withdrawal of the remnants of the Persian fleet towards Phoenicia or Asia Minor. The loss of its naval hegemony in the Aegean meant that the Persian navy no longer posed any direct threat to the ports of Chalcidice. However, the situation was quite different on land, where the army of Xerxes remained largely unscathed. As a result, the communities of Pallene maintained their loyalty, at least until the departure of the Great King.

With Xerxes out of the picture, Pallene finally revolted, although Artabazus' escort remained in the vicinity. Given the close proximity of Artabazus' army, the decision may appear at first rather unsound, but there is always the chance that the rebels had been misinformed about the disposition of the Persian troops. As Xerxes' departure had been confirmed, the Potidaeans and their companions could have arbitrarily assumed that the entirety or at least the majority of his escort had followed him in Lydia. Such a move would have crucially weakened the Persian military strength in the region, considering that Mardonius was camping in Thessaly and that his immediate target was the Greek cities of the south and not the rebels of the north. In fact, the only noteworthy imperial forces in the region were probably just the garrisons in the forts of Eion and Doriscus, situated respectively in the deltas of the Strymon and Evros rivers. ${ }^{24}$ In any case, the fact that Artabazus was actually incapable of assaulting Potidaea, presumably because of the lack of siege engines, indicates that the rebels were at least partly justified in their decision, even if they may have underestimated the military power possessed by Artabazus.

\section{The Isthmus of Potidaea}

Consequently, it is concluded that the requisitions, conscription and crop devastation were responsible for damaging the relationship between the Achaemenid Empire and the communities of Chalcidice, while the departure of Xerxes was the spark that ignited the fire of the revolt. However, the aforementioned factors applied to the entirety of Thrace and Macedonia, but Pallene was the only region to revolt, as Herodotus does not mention the outbreak of any other rebellion. In fact, although Herodotus underlines, in a hyperbolic and rhetorical manner, ${ }^{25}$ that the Persians were annihilated by hunger, dysentery and pestilence, ${ }^{26}$ no military opposition is mentioned during either Xerxes' departure or Artabazus' return. So, is the reason behind the exception of Pallene the inaccurate intelligence the Potidaeans received or is so-

${ }^{24}$ For a brief but concise summary of the information available about Eion and Doriscus, especially in regards to their status as fortresses manned by Persian garrisons, see Bacheva 2016: 12-13.

${ }^{25}$ Macan 1908: 542.

${ }^{26}$ Herodotus, VIII, 115, 2-3. 
mething else to blame? As noted above, the circulation of inaccurate rumours about the deployment of the Persian troops is a reasonable hypothesis, but the possibility that only the Potidaeans were affected by them is extremely unlikely. On the other hand, Burn highlights ${ }^{27}$ the links of Potidaea with Corinth, her metropolis and also one of the leading members of the anti-Persian coalition, to explain the revolt, but his argument does not appear convincing. ${ }^{28}$

On the contrary, the answer to the question of why Pallene reacted in such an extraordinary manner, not imitated by any other community, including the Thracian tribes and the kingdom of Macedonia, probably revolves around its geographical particularities. ${ }^{29}$ Namely, the hilly peninsula of Pallene is linked to the mainland only across a very narrow isthmus, whose maximum length is approximately 1.000 meters. ${ }^{30}$ Exactly to the south of that isthmus lies Potidaea and the rest of the peninsula, including the towns of Scione, Sane, Mende etc. To the west and the east, are located respectively the Thermaic and Toronean gulfs. The only way for an army to circumvent this formidable natural obstacle is through an amphibious operation, but, as already mentioned, the departure of the imperial fleet deprived Artabazus of the necessary transport vessels and thus of the possibility of assaulting the rebels from the sea.

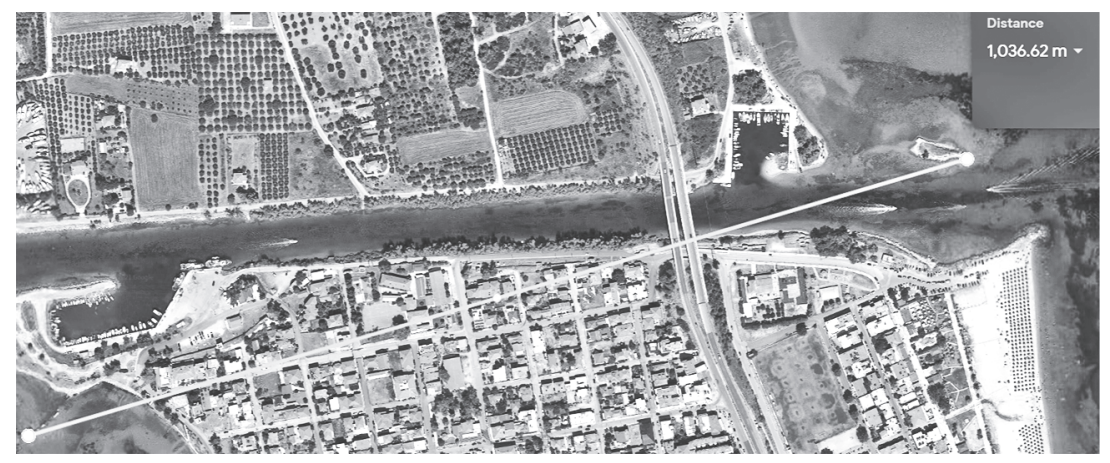

Fig. 2: The distance in a straight line from the easternmost to the westernmost fortifications of Potidaea

The hilly and not easy to traverse isthmus was defended by the fortifications of Potidaea, which could easily protect the northern side of the city, while the west, east and south remained totally invulnerable to any invader from the north that possessed no means of naval transportation. Its natural inaccessibility also meant that Potidaea was

${ }^{27}$ Burn 1962: 496-497. See also Lazenby 1993: 254.

${ }^{28}$ Green 1996: 217-218.

${ }^{29}$ The importance of geography is sometimes recognized, but generally treated in a rather brief manner (Hignett 1963: 270-271 and Balcer 1984: p. 267).

${ }^{30}$ Müller 1987: 193. 
practically impossible to be starved into submission. On the contrary, the rebellious city could be amply equipped with military reinforcements and provisions from the south and across the sea, both of which lied beyond the reach of the Persians, whose naval power in the Aegean Sea no longer remained undisputed. Consequently, there was no alternative to Artabazus other than storming the city by force, as the incomplete blockade could never seriously undermine the morale of its defenders. However, as Artabazus apparently did not possess any siege train, ${ }^{31}$ even the option of a frontal assault was hardly feasible.

Moreover, Potidaea being the strategic key to the peninsula meant that the rest of Pallene's communities could also defy the Persian authorities, despite their limited defenses, size and resources, without taking any serious risk, as long as Potidaea succeeded in repulsing the besiegers. In fact, the wider strategic value of Potidaea is also illustrated through the archaeological remains of the Roman wall, dated ${ }^{33}$ in the reign of emperor Justinian I (527-565 A.D.). No visible ruins of the Classical era's fortifications have been excavated so far,${ }^{34}$ but the fact that the Roman administration spent such a considerable amount of resources to bolster the defenses of Potidaea confirms the isthmus' continuous strategic value. The walls and towers were presumably designed to prevent the raids of the Avars and of the various Slavic tribes, ${ }^{35}$ which, similarly to Artabazus, also lacked the ships and siege

${ }^{31}$ Hignett 1963: 271.

${ }^{32}$ Persian armies had used siege engines to overcome the defenses of rebellious settlements. Boulders discovered in Phocaea and Cyprus may actually indicate the first known use of catapults by a besieging army, more than one century before the campaigns of Dionysius of Syracuse (Briant 1996: 783). On the possibility that the stones were actually thrown by the defenders and not by the besiegers, see Lazenby 1993: 31 . In the case of the siege of Potidaea, the absence of any siege engines is probably explained by the logistical difficulties involved in transporting such massive constructs for the needs of a relatively secondary front.

${ }^{33}$ Procopius, The Buildings, IV, 3, 20-26. Procopius explains that Justinian rebuilt the fortifications of Pallene, because the ancient wall (a reference probably to the Hellenistic wall of the city, constructed when the Antipatrid king Cassander rebuilt Potidaea, renaming it as Cassandreia), having already fallen in disrepair, was completely demolished by a Hunnic raiding party.

${ }^{34}$ On the possible traces of the foundations of the Classical era's fortifications, see Alexander 1963: 2-3. Herodotus himself does not explicitly refer to a wall separating Potidaea from the interior of Chalcidice, but its existence is indicated by the efforts of Artabazus to circumvent the Potidaean defenses by taking advantage of the ebb tide. Additionally, Diodorus (XII, 46, 3) and Thucydides (I, 63, 2) underline the existence and the role of the Potidaean wall in their accounts about the siege of Potidaea by the Athenians (432-429 B.C.). Finally, Strabo attests (VII, Fr. 25) that a canal had been cut through the isthmus of Pallene. The primary purpose of the canal in question must have been to facilitate the maritime contact between the Toronean and the Thermaic gulfs, but it could also play a defensive role. However, the date of the canal's construction remains unclear.

${ }^{35}$ Since the reign of Justinian and during the $7^{\text {th }}$ century A.D., Avar and Slavic tribes were crossing the Danube, with the aim of either plundering or establishing themselves on 
engines necessary to overcome the challenge posed by the narrow and fortified isthmus.

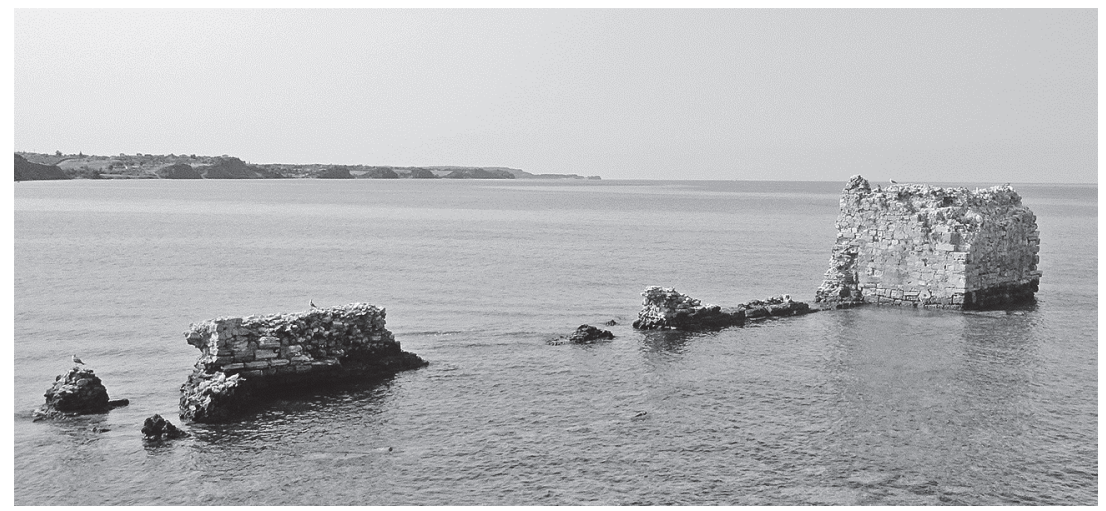

Fig. 3: The ruins of the westernmost tower of Potidaea's Roman fortifications partly submerged in the Thermaic gulf (photograph taken at 11 Aug. 2021)

However, the communities situated outside the protection of Potidaea's isthmus had much fewer chances of resisting against the Persian counter-attack. Olynthus, for instance, which Herodotus places in Sithonia ${ }^{36}$ but which lied more to the west, in the part of Chalcidice linking Pallene and Sithonia, was easily subdued by Artabazus, as, unlike Potidaea, it could be encircled and isolated by a land army. A similar example to Olynthus might have been Torone, a small Chalcidicean town situated on the southwestern edge of the peninsula of Sithonia, which, in contrast to Pallene, was not protected by any narrow and fortified isthmus. Herodotus mentions that Artabazus surrendered Olynthus to a certain Critoboulus of Torone. Outside this not particularly informative remark, the political career of Critoboulus remains rather obscure, but his appointment as the ruler of the conquered settlement, as well his obvious collaboration with Artabazus, strongly imply that his home town stayed loyal to the Persians and may have also actively contributed to the suppression of the uprising. ${ }^{37}$ To recapitulate, it is observed that the communities that were located outside the protection of the narrow isthmus of Pallene were either quickly subdued by the Persians or actually cooperated with them, while those to the south actively opposed them.

Roman territory. The subsequent migrations seriously disrupted the status quo of the Roman Balkans, especially in the countryside, and encouraged the Roman authorities to enact a policy of ameliorating the defenses of the region. A typical example of this strategy is the $6^{\text {th }}$ century wall of Potidaea. For the construction and improvement of military infrastructure in Greece during that period, including the similar case of the isthmus of Corinth, see Daly 1942: 505-508.

\footnotetext{
${ }^{36}$ Herodotus, VII, 122.

${ }^{37}$ Green 1996: 218.
} 
Given the aforementioned advantages of Potidaea's position, which rendered the city essentially impregnable for any army that lacked siege engines and naval support, it can be easily understood why the front quickly stagnated with neither side being able to visibly progress against its opponent. As the story about the damaged sanctuary of Poseidon in the city's outskirts indicates, Artabazus had camped in close proximity to Potidaea, presumably a bit north from the isthmus, but he was unable to scale the walls, at least not without sustaining unacceptable casualties. ${ }^{38}$ He thus chose other, more diplomatic means, in order to surpass the rebels' defenses. The negotiations with Timoxenus of Scione are generally marked by the extraordinary story of how the two sides communicated with each other, without raising any suspicions. The details of the arrow-trick may have been a bit embellished, ${ }^{39}$ but the most important observation that can be deduced from that diplomatic affair is that Artabazus was not very optimistic over the prospects of capturing Potidaea by force. On the contrary, the Persian general was apparently ready to undermine his adversaries' resistance from within, in a plan that would inevitably involve the assistance of a faction inside the city's walls.

On the other hand, the willingness of Timoxenus and the Scionean regiment to at least listen to the proposals of Artabazus also reveals the superficial unity of the rebels. The Potidaeans may have been adamant about resisting against the Persians, but the same conclusion evidently does not apply for Scione. The attitude of the rest of Pallene's smaller communities cannot be extrapolated with absolute certainty solely from Timoxenus' actions, but it is probable that the coalition of the rebels was actually more fragile than what might appear on the surface. Potidaea being demographically, economically and militarily

${ }^{38}$ The defensive capabilities of Potidaea were also demonstrated during the siege of the city by the Athenians in the early stages of the Peloponnesian War (Diodorus, XII, 34, 3-4; 37, 1; 46 and Thucydides, I, 64-65; II, 58, 70). Despite the Athenians having encircled the city from every side and having established naval supremacy in the region (unlike the Persians), the siege lasted for three years (from 432 to 429 B.C.), until the final submission of the city. For a study of the siege of Potidaea by the Athenians, especially in what concerns the political and diplomatic background of the conflict, see Alexander 1963: 70-78 and Kagan 1969: 273-285. On the contrary, Philip II's siege of Potidaea (356 B.C.) is presented much more briefly (Diodorus, XVI, 8, 3-5), but this reflects more the telegraphic structure of the Historical Library than the resilience of the defenders and the actual duration of the siege, which lasted for a few months. For the Macedonian siege of Potidaea and its repercussions, see Alexander 1963: 88-91.

${ }^{39}$ The historicity of the trick might appear a bit dubious, but it does not constitute a unique instance in Greek-Latin historiography. The same method, albeit more successfully, was allegedly also employed during the Roman conquest of Gaul. When a Roman camp under Quintus Tullius Cicero (brother of the famous orator Marcus Tullius Cicero) was besieged by a group of Belgic tribes under Ambiorix, a messenger from Caesar managed to bypass the besiegers by fastening Caesar's letter to his spear, which he then threw into one of the camp's towers, thus succeeding in not permitting the Belgae to intercept the confidential message (Gaius Julius Caesar, Gallic War, V, 48). 
the most powerful city in Pallene, there is a strong chance that a certain level of coercion was employed in the decision of the rest of the communities to join the rebellion. This hypothesis is further corroborated by the refusal of the Potidaeans to punish Timoxenus for an act that could be undeniably labeled as open treachery. Herodotus justifies the seemingly inexplicable leniency of the Potidaeans in very noble terms, but his argument seems hardly convincing.

On the contrary, it gives the impression of being a dubious excuse, invented by Herodotus' source, in order to absolve the Potidaeans for their inaction. It is much more probable that the Potidaeans hesitated to reprimand Timoxenus, in order not to alienate Scione and the rest of the communities of Pallene, which might have also been sympathetic towards a conciliatory initiative. Since the conspiracy had already collapsed, from the perspective of the Potidaeans, there was no point in threatening the already loose cohesion of the rebel coalition, by reacting in a directly hostile manner against the military leader of Scione. Compromise and conciliation were thus the only available options, as Potidaea could not politically and militarily afford an alternative, more drastic and bloodier solution. So, the efforts of both sides were hampered by their military and political weakness, leading to a situation of total stagnation, with neither side being capable of decisively defeating its enemy.

\section{The Climax of the Drama}

At that moment of total stalemate, the tone of the narration transforms dramatically, as the Persians suddenly gained the upper hand, thanks to a seemingly miraculous ebb, only for a complete reversal of the fortunes of the battle to occur, as the tidal wave returned, with the helpless soldiers of the imperial army either drowning or being disposed of by the pursuing Potidaeans. As already noted, the credibility of Herodotus' tsunami story is already put in doubt, given the supernatural explanation of divine intervention he cites. However, the possibility of a spectacular natural disaster so heavily determining the fate of a campaign belonging to one of the most famous conflicts of the Antiquity has been proven too fascinating to be dismissed so casually. ${ }^{40}$ The possibility of a simple tide is usually rejected, as the Aegean tides are too small to cause such a catastrophe, so the hypothesis of a tsunami caused by an earthquake is preferred instead.

\footnotetext{
${ }^{40}$ For a relatively recent article that accepts Herodotus' account essentially on its entirety, see Stefanakis 2006: 7-8. Generally speaking, in the majority of books, articles and chapters dealing with the Median Wars, the "tsunami passage" is treated with some skepticism, but it is not outright dismissed as fiction. Indicatively, see Munro 1953: 316, Burn 1962: 498-499, Hignett 1963: 271, Hammond 1988: 586-587, Lazenby 1993: 206-207, Green 1996: 219 and Vasilev 2015: 197.
} 
In a recent seismological study of the Thermaic Gulf and its environs,${ }^{41}$ it was observed that powerful seismic activities and the subsequent creation of tsunamis are theoretically possible. Moreover, excavations at the archaeological site of Mende, located in the southwestern portion of the Pallene peninsula led to the discovery of a marine layer, which was dated, with the help of the radiocarbon method, approximately in the beginning of the $5^{\text {th }}$ century B.C.. The marine layer includes building debris, gravel and paleontological elements (mostly shell fragments from the gulf's submarine fauna), all of which indicate that a tsunami could have indeed taken place in the Thermaic Gulf around the time Xerxes invaded the Greek city states.

The press responded to the study's observations in a rather enthusiastic manner, assuming that the findings verified Herodotus' account. ${ }^{42}$ The contributions of geology and archaeology on the matter are indeed important, but caution is advised, in order to avoid arbitrary extrapolations, despite the temptation to confirm the accuracy of Herodotus' story. Firstly, the seismological examination of the Thermaic gulf and the oyster relics only indicate that a tsunami could have happened in the winter of 480/479 B.C., but they do not constitute an irrefutable proof of its occurrence. It may have happened earlier or even later than the Persian wars and it might not even have gravely affected Potidaea.

Moreover, Herodotus' story is considered incredible, not only due to the extremely improbable chance of a tsunami perfectly coinciding with the siege of Potidaea, but also because Herodotus' brief description does not in fact correspond to how tsunamis actually hit the coastline. More specifically, according to the Histories, after having noticed the waters receding, Artabazus gathered his soldiers and launched an assault party against the city, which actually managed to cross a remarkable part of the distance (the two fifths, ${ }^{43}$ to be precise), before it got wiped out by the tsunami. However, the time distance between the ebb and the tidal wave is actually particularly short, as the tsunamis crush on shore in a matter of only a few minutes (especially in relatively narrow bodies of water, like the Thermaic Gulf and the even smaller Toronean one). Such a limited time-span would never suffice for the Persians to complete all the necessary manœuvres of mobilising and deploying an adequate assault force, which allegedly managed

\footnotetext{
${ }^{41}$ Mathes-Schmidt, Pallikarakis, Papanikolaou, Reicherter 2019: 101-125.

${ }^{42}$ For three typical examples representing the French, British and Greek media, see respectively Barthélémie, Pierre. "La vengeance de Poséidon était bien un tsunami", Le Monde, published at 29 April 2012,"Persian Invaders of Greece «Did Perish in Tsuna-

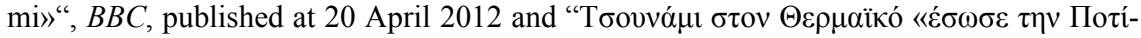

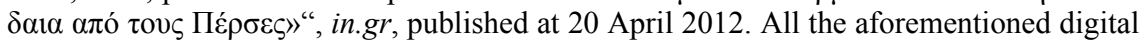
articles were accessed at 11 June 2021.

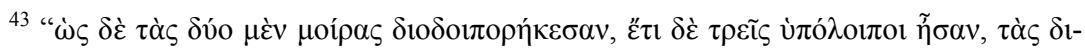

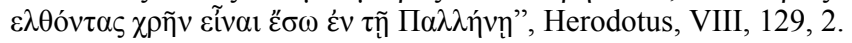


to cross the beach and even cover a significant part of the distance between the Persian camp and the port of Potidaea.

In conclusion, taking into consideration all these inconsistencies and contradictions, ${ }^{44}$ the story of Herodotus should probably be rejected as an elaborate invention. Of course, the possibility of the tsunami story and the deux ex machina rescue of Potidaea having been indeed inspired from a real event, ${ }^{45}$ whose dimensions were then grossly exaggerated, cannot be totally excluded. Perhaps the Persians' siege works were indeed damaged, as a result of unfamiliarity with the local tides. Alternatively, the flood documented by the findings at Mende may have actually affected Potidaea too, but was chronologically completely irrelevant to the battle against Artabazus and was only later attributed to the time of the Persian siege. Another indication that the connection between the tsunami and the victory against the Persians was invented by the Potidaeans afterwards is the fact that Poseidon, the patron deity of Potidaea and Corinth, ${ }^{46}$ Potidaea's metropolis, is associated in Greek mythology with the sea and seismic activities. ${ }^{47}$ Thus, there is a strong possibility that the Potidaeans linked the Persian defeat to a tidal marine wave, probably caused by an earthquake, in an effort to honour the patron deity of their community.

In any case, what matters most is that almost certainly neither did the natural disaster occur at the time of the Persian siege nor did it decimate the expeditionary force. In fact, even if the tsunami episode is removed altogether, the history of the siege does not seem incomplete or incoherent. As previously explained, the military operations had stagnated, because Artabazus did not possess the necessary means to bypass Potidaea's defenses. On the other hand, he sought refuge to diplomacy and subterfuge, in an ultimately futile attempt to undermine the unity of the rebel coalition. Thus, it can be concluded that Artabazus, having failed to overcome the Potidaeans, simply abandoned the

${ }^{44}$ Additionally, it could be argued that the credibility of the tsunami story is further undermined by the fact that nowhere in the Histories is an earthquake, the essential requirement for the generation of a tsunami, mentioned. However, theoretically speaking, the hypocentre of the earthquake's depth could have been large enough to provoke a tsunami, but the geological disturbance would not have been felt by the residents of Potidaea. Alternatively, it has also been suggested that the tsunami could have been the result of a volcanic eruption (Alexander 1963: 34), a meteorological phenomenon or a submarine landslide (Ambraseys 2009: 81). All these alternative explanations suffer however from the same problems as the earthquake theory does, so neither of them makes Herodotus' account more credible.

${ }^{45}$ For a short collection of references to tsunamis Greek literature, see Smid 1970: $100-104$

${ }^{46}$ The importance of Poseidon in Potidaea's religious and civic symbolism can be most clearly detected in the city's numismatic iconography. The figure of Poseidon, holding a trident and riding a horse, is depicted in Potidaea's silver tetradrachms, dated between 500 and 480 B.C., chronologically very close to Artabazus' expedition (Alexander 1953: 206-208 and Rodríguez-López 2019: 268-270).

${ }^{47}$ On Poseidon's “seismic” aspect, see Güney 2015: 294-297. 
siege, as he had more urgent priorities. Not only had winter already arrived, which would inevitably cause a severe decline in the available provisions in the already relatively barren land of Chalcidice, but he was also supposed to unite with Mardonius' main army in Thessaly. The primary goal of the campaign was not the punishment of seditious Pallene, whose isolated position did not threaten the logistical lines of communication with the east, ${ }^{48}$ but a decisive victory over the Greek alliance in the south. In summary, having failed to militarily subdue, starve or diplomatically divide the rebels of Pallene, Artabazus was obliged to move southwards, as he ought to combine his force with that of Mardonius, before the temporary lull of operations in the Greek front the winter had brought would come to an end.

Finally, it is interesting to note that the involvement of Potidaea in the Persian Wars does not stop with Artabazus' withdrawal. As Herodotus attests, ${ }^{49}$ Potidaea sent a military contingent of 300 men in Plataea to fight together with the rest of the Greeks. The limited size of the involved detachment renders Potidaea's contribution to the conflict largely symbolic, but it still underlines the vehement opposition of the city to the Persians. As for the motives behind that initiative, only speculations can be made: In idealistic terms, it can be viewed as a manifestation of Panhellenic solidarity in the fight against the common "barbarian" enemy, but the intervention could also bring more practical benefits for Potidaea. Defeating the main Achaemenid army was of crucial importance for Potidaea or otherwise the victorious Persians, no more hindered by the Greek coalition, could now focus their attention on crushing the rebels of Pallene with overwhelming numbers and resources. Moreover, merely the participation in the final engagement would place Potidaea solidly in the winning camp, guaranteeing to the town of Pallene a somewhat privileged position in the aftermath of Xerxes' ultimately unfortunate invasion.

\section{Potidaea, Chios and Samos}

To recapitulate, we notice that the defeat at Salamis, the subsequent departure of Xerxes and the decline of Persian naval power in the Aegean did not lead to the immediate disintegration of Persian authority in the southern Balkans, except for Pallene's isolated case. On the contrary, Herodotus mentions no confrontation with the Thracian tribes, while the Macedonian ruler Alexander I remained with Mardonius' army. ${ }^{50}$ This is in stark contrast to the aftermath of Plataea, when

${ }^{48}$ Green 1996: 218.

${ }^{49}$ Herodotus, IX, 28, 3; 31, 3. On the historical reliability of Herodotus' claim about the Potidaeans' involvement in Plataea, see Alexander 1963: 34-37 and Hignett 1963: 436. For a more skeptical approach, see Munro 1953: 323.

${ }^{50}$ The policy of the Macedonian ruler, Alexander I, during Xerxes' invasion is notoriously ambiguous. Alexander is portrayed in a noticeably positive manner in the Histo- 
Alexander deserted the Persians and the Thracians harassed the Achaemenid soldiers, during the retreat of Artabazus. ${ }^{51}$ From the abo$v e$, it is deduced that, in spite of the relative weakening of Persian strength in the area and the frustrations caused by the fiscal and military demands of the imperial authorities, the indigenous communities showed no signs of disloyalty after Salamis, largely due to the threat still posed by the Persian armies under Mardonius and Artabazus. The only exception is Pallene, which, under the leadership of Potidaea, successfully defied the Persians earlier than the rest. The rebels may have been misled by false news about Artabazus' departure, but the decisive factor behind this divergence concerned the defensive advantages provided by the narrow isthmus of Potidaea. The isthmus shielded the entire peninsula from any potential reprisals coming from a land-based force, thus permitting Pallene to manifest its centrifugal tendencies more freely and in a less risky manner.

The conclusion about the importance of geographical factors in determining the loyalty of local communities to the Achaemenid dynasty is corroborated by a similar incident in the eastern Aegean, which, however, unlike Pallene, did not escalate into an open and violent uprising against the Persians. Namely, Herodotus reports the arrival of a delegation from the island of Chios to Aegina, where the Greek fleet was moored. ${ }^{52}$ The Chians had unsuccessfully plotted against the tyrant Strattis, who ruled the island with the approval of the Persians. ${ }^{53}$ Their conspiracy having failed, they asked for the help of the Greeks to depose Strattis. The Greeks were hesitant, fearing the power of the Achaemenid fleet, but a second embassy from the island of Samos, asking them to intervene, in order to ignite an anti-Persian rebellion, convinced the commanders of the navy to sail eastwards. ${ }^{54}$ The exact nature of the grievances of the Chians and Samians with the Persians is not clear. In the former case, the principal target was the tyrant Strattis, who was also a loyal client of the Persians, but the mission of the Samians is painted in more anti-Persian colours. However, Herodotus also adds that the Samians approached the Greeks without

ries of Herodotus, but the Argead monarch's stance during the war appears quite ambivalent, despite his supposed demonstration of Philhellenic sentiments. For a summary of the instances of Alexander's positive depictions by Herodotus, as well a persuasive hypothesis about the Macedonian ruler being a direct source to the author of the Histories, see Vasilev 2016: 41-46.

${ }^{51}$ Herodotus, IX, 89, 4.

${ }^{52}$ Herodotus, VIII, 132, 2.

${ }^{53}$ Herodotus also mentions (IV, 138, 2) a Chian tyrant named Strattis during the reign of Darius I. He might have been the same man, but given the fact that the first Strattis had participated in the Scythian expedition, more than 30 years before Xerxes' invasion, the second Strattis may have been alternatively a descendant of the first one, who simply shared the same name with his ancestor and predecessor.

${ }^{54}$ Herodotus, IX, 90, 1 - 96, 1. See also Diodorus, XI, 34, 2-3. 
the knowledge of the tyrant Theomestor, ${ }^{55}$ a remark which implies that internal politics may have also played a role in the decision of the Samians to seek the help of the Greeks. ${ }^{56}$

The intervention eventually culminated into the battle of Mycale and the gradual and partial loss of the western Anatolian coastline to the Athenians, but what matters most for the subject of the present study is the geographical particularities of the two instigators of the Greek intervention, Chios and Samos, where movements hostile (even indirectly, if we accept the strong possibility that the abolition of the tyrannical regimes was the greatest priority) to Persian interests were firstly manifested. ${ }^{57}$ Similarly to Pallene, the islands of Samos and Chios were essentially impregnable without the control of the seas. The islands of northeastern Aegean thus enjoyed an invaluable geographical advantage, which significantly determined their relationship with the Persian Empire, even before Xerxes' invasion. Namely, from the safety provided by the sea, the Chians and the Lesbians were able to negotiate with Mazares, the Median general of Cyrus II, the price of Pactyes, the Lydian fugitive who had sought refuge to the islands following the collapse of his revolt. ${ }^{58}$ Moreover, during the reign of Cambyses II, Oroetes, the Persian satrap of Lydia, managed to arrest Polycrates, the tyrant of Samos, only after the latter was convinced to abandon the safety of his island and to disembark on the Anatolian coast, as a result of an elaborate ruse orchestrated by Oroetes. ${ }^{59}$

Therefore, Samos and Chios enjoyed an elevated degree of autonomy from the principally terrestrial power of the Lydians and the Persians under Cyrus. This strategic privilege was however lost, following the establishment of the Persian naval power under Cambyses

${ }^{55}$ Herodotus, IX, 90, 1. According to Herodotus (VIII, 85, 2-3), Theomestor was appointed ruler of Samos by Xerxes, thanks to his praiseworthy performance during the battle of Salamis. This nomination has been interpreted as an attempt by Xerxes to consolidate his authority in the dangerously exposed island, in the aftermath of the defeat at Salamis (Will 1969: 306). It is interesting to note that Theomestor has even been described as a Greek Quisling (Barron 1988: 611), in a clear reference to Vidkun Quisling, the head of the Norwegian puppet government installed by the Third Reich, whose name is a synonym for treason and collaboration with the Germans.

${ }^{56}$ This suspicion is further reinforced by the fact that the image of the Samians is consistently embellished in the Histories of Herodotus, especially in regards to their contribution to the fight against the Persians (Balcer 1984: 274, Irwin 2009: 395-416 and Pelling 2011: 7-18).

${ }^{57}$ That being said, the extent of the opposition to the tyrannical regimes and to the Persians should not be overestimated. The conspirators were unable to achieve their goals without the contribution of the Greeks, while the fact that the hostility to Strattis manifested itself in the form of subterfuge, instead of an open uprising, indicates that the intriguers lacked any serious popular support (Sealey 1966: 243-247).

${ }^{58}$ Herodotus, I, 160-161. For a recent and thorough study of Pactyes' rebellion, see Rung 2015: 7-22.

${ }^{59}$ Herodotus, III, 122-125. 
$\mathrm{II},{ }^{60}$ which allowed the Persians to extend their authority overseas. The imposition of Persian suzerainty, in combination with the demands for tribute, ships and crews, inevitably caused great disaffection among the previously independent islanders, which might also be reflected to their disproportionately large involvement in the Ionian Revolt. ${ }^{61}$ The reversal of the military balance in the Aegean, as a result of the defeat at Salamis and the partial withdrawal of the Persian fleet, allowed the opposition to express its anti-Persian feelings more freely than the cities of mainland Ionia.

This reaction was however limited in scope and numbers. It concerned only Pallene, Chios and Samos, accessible only through the sea and thus largely immune to a potential Persian counter-attack. Even there, the hostility to the Persians was far from unanimous, as the examples of Scione, Strattis and Theomestor confirm. After all, it is very unlikely that these seditious initiatives would have come to fruition, had the southern Greeks not intervened decisively. Persian authority over Samos and Chios only collapsed after the disaster at Mycale, ${ }^{62}$ while Artabazus was forced to abandon the siege of Potidaea, not

${ }^{60}$ For the creation, mobilisation, structure and organisation of the Persian navy under Cambyses and his successors, see Wallinga 1987: 52-72. For a counter-argument against Wallinga's thesis, which does not accept his conclusions, at least in regards to the Ionian squadrons of the imperial fleet, see Cawkwell 2005: 255-273.

${ }^{61}$ In the order of the battle of Lade, whose outcome sealed the fate of the rebellion, Herodotus enumerates (VI, 8) 100, 70 and 60 warships for the Chians, Lesbians and Samians respectively, in a total of 353 ships for the rebel fleet. The islanders composed therefore the absolute majority of the naval ships of the Ionian coalition, while the Milesians, the original instigators of the revolt, contributed with 80 ships, more than the Lesbians and the Samians, but significantly fewer than the Chians.

${ }^{62}$ To be precise, Herodotus closes (IX, 104) his description of the battle of Mycale by noting that in this way the Ionians revolted for a second time against the Persians, but without elaborating on this rather cryptic remark. Thucydides repeats $(I, 89,2)$ this statement, but, similarly to Herodotus, without any further clarification. It could be a reference to the aftermath of the battle, but no sources whatsoever, Herodotus included, report any anti-Persian revolts. Alternatively, it could concern the behaviour of the Ionians during the engagement. On this regard, Herodotus attests (IX, 99) that the Persians disarmed the Samians and ordered the Milesians to guard the paths leading to the summits of Mycale, because they suspected their loyalty (for the logical inconsistency of the claim about the Milesians, given the strategic importance of the task entrusted to them by the Persians, see Macan 1908: 805-806, Hignett 1963: 255 and Balcer 1984: 274). Herodotus then reports (IX, 103-104) that in the middle of the battle the Samians helped the Greeks as much as they could, thus inspiring the rest of the Ionians to imitate their example, while, following the Persian defeat, the Milesians disorientated the Persian fugitives. However, the claim about the Samians is doubtful, given the already mentioned bias of the Histories in their favour, as well as the fact that they had been supposedly disarmed by the Persians, while the behaviour of the Milesians, even if true, qualifies more as opportunistic mutiny than open rebellion (Hammond 1967b: 44, Harris 1971: 271, Balcer 1984: 274 and Green 1996: 283). Therefore, the reference of Herodotus to a second Ionian uprising serves more as an epilogue for his work revolving around the Greco-Persian Wars, by completing the circle originally initiated by the outbreak of the Ionian Revolt (Meiggs 1972: 36). On the other hand, Diodorus, whose Historical Library is the second narrative source about My- 
as a result of the presumably fictitious tsunami, but because he needed to move his army in the winter headquarters of Thessaly together with Mardonius and to prepare for the final clash with the Greeks in the upcoming campaign season. The resilience of Persian power in the region is also demonstrated by the fact that the Persian garrisons in Doriscus and Eion, under Mascames and Boges, situated in the deltas of the Evros and Strymon rivers respectively, were able to resist against the Athenian offensive for several years. ${ }^{63}$

From the above, it is concluded that the decline of Persian authority in the southern Balkans and the surrounding regions was the consequence not of a sudden disintegration, but of a more gradual progress. In the early stages, the Persian domination remained largely intact, with the exception of the isolated example in Pallene, as the subject communities, despite the disaffection caused by the arbitrary requisitions and fiscal demands, not only were reluctant to challenge the Persians, but they were even willing to cooperate with them at the expense of their neighbors, as the case of Critoboulus of Torone reveals. However, the strategic position of the Persians subsequently deteriorated, following the definitive defeats of their fleet and army at Mycale and Plataea respectively, which encouraged the Macedonians and the Thracians to opportunistically abandon their allegiance to the Persians and to even harass the retreating troops. The decisive factor however was the ascending Greek naval power, which prevented the Persians from responding effectively to the revolt of Potidaea and led to the eviction of the Achaemenid troops from the Ionian islands and parts of the Anatolian littoral. ${ }^{64}$

cale, is much more explicit than Herodotus about the scale and contribution of the Ionian "revolt" during the battle of Mycale. Diodorus underlines (XI, 36, 2-5) that the Samians and the Milesians had unanimously decided to rise against the Persians, even before the skirmish commenced. Then, in the heart of the fighting, they rebelled, joined by the Aeo-

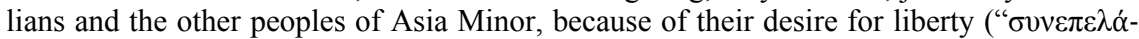

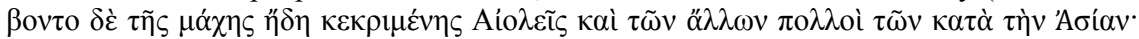

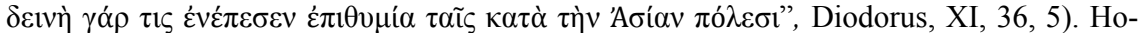
wever, the historical reliability of Diodorus' account is dubious at best. Not only because the Historical Library was written several centuries after Xerxes' invasion, but also due to the Panhellenic sympathies of Diodorus and one of his main sources, Euphorus of Cyme (for the role of Euphorus in the Historical Library and especially its $10^{\text {th }}$ and $11^{\text {th }}$ books, see Green 2006: 24-28 and Lenfant 2011: 126). In fact, the influence of the latter, a native of Aeolis, as his epithet suggests, is why Diodorus highlights especially the involvement of the Aeolians in the alleged uprising against the Persians (Hignett 1963: 257, Hammond 1967b: 45 and Heinrichs 1989: 58-59).

${ }^{63}$ The fall of Eion is generally dated at 476/475 B.C., following the remark of Thucydides $(I, 98,1)$ that the attack against it constituted the first operation launched by the Delian League. The case of Doriscus is however more ambiguous (Vasilev 2015: 225-226), as it is even suggested that the Persians might have been still holding the fortress, by the time Herodotus was writing his Histories.

${ }^{64}$ The extent of the Persian territorial losses remains opaque, as the literary sources refrain from making any clear references on this regard. One possible indication could be 


\section{BIBLIOGRAPHY}

Alexander, John A. "The Coinage of Potidaea", Studies Presented to David Moore Robinson, vol. II, edited by George E. Mylonas and Doris Raymond, Saint Louis: Washington University Press, 1953, p. 201-217.

Alexander, John A. Potidaea: Its History and Remains. Atlanta: University of Georgia Press, 1963.

Ambraseys, Nicholas N. Earthquakes in the Mediterranean and Middle East: A Multidisciplinary Study of Seismicity up to 1900. Cambridge: Cambridge University Press, 2009.

Bacheva, Galya D. "Detecting a Satrapy: The Skudra Case", Thracia, vol. 20, 2016, p. 1126.

Balcer, Jack M., "The Date of Herodotus IV.1 Darius' Scythian Expedition", Harvard Studies in Classical Philology, vol. 76, 1972, p. 99-132.

Balcer, Jack M. Sparda by the Bitter Sea: Imperial Interaction in Western Anatolia. Chico: Scholars Press, 1984.

Balcer, Jack M. A Prosopographical Study of the Ancient Persians Royal and Noble, c. 550-450 B.C.. New York: Edwin Mellen Press, 1993.

Balcer, Jack M. "The Liberation of Ionia: 478 B.C.”, Historia, vol. 46.3, 1997, p. 374377.

Barron, John P. "The Liberation of Greece", The Cambridge Ancient History, Cambridge: Cambridge University Press, 1988, p. 592-622.

Briant, Pierre. Histoire de l'empire perse: de Cyrus à Alexandre. Paris: Fayard, 1996.

Burn, Andrew R. Persia and the Greeks: The Defence of the West, 546-478 B.C.. London: Arnold, 1962.

Cameron, George G. "Darius the Great and his Scythian (Saka) Expedition. Bisutun and Herodotus", Acta Iranica: Monumentum H. S. Nyberg I, Tehran: Bibliothèque Pahlavi, 1975, p. 77-88.

Cawkwell, George. The Greek Wars: The Failure of Persia. Oxford: Oxford University Press, 2005.

Daly, Lloyd W. "Echinos and Justinian's Fortifications in Greece", American Journal of Archaeology, vol. 46.4, 1942, p. 500-508.

Dandamaev, Muhammad A. A Political History of the Achaemenid Empire. Leiden: Brill, 1989.

De Romilly, Jacqueline. "La vengeance comme explication historique dans l'œuvre d'Hérodote", Revue des Études Grecques, vol. 84, 1971, p. 315-328.

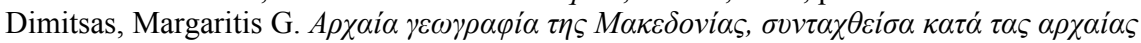

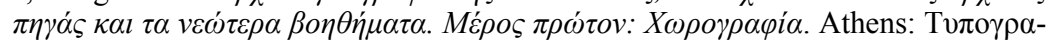

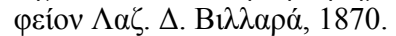

Elayi, Josette. Histoire de la Phénicie. Paris: Perrin, 2013.

Frye, Richard N. The Heritage of Persia. Costa Mesa: Mazda, 1962.

Gardiner-Garden, John R. "Dareios' Scythian Expedition and its Aftermath", Klio, vol. 69, 1987, p. 326-350.

provided by the Athenian Tribute List $\left(I G \mathrm{I}^{3} 259\right)$, but it is not chronologically close to the battle of Mycale. Given the fact that the Greeks limited their early operations in Europe, against Sestos and Byzantium (Diodorus, XI, 37, 4-5, Herodotus, IX, 115-118 and Thucydides, I, 89; 94, 2), it is generally assumed that the withdrawal of the Persians from the western coast of Asia Minor was a slow and gradual process, with parts of the coastline actually remaining in Persian hands (Sealey 1966: 242-246, Briant 1996: 551, Balcer 1997: 376-377 and Maffre 2014: 70). For an opinion towards the opposite direction, see Gomme 1956: 290-295. 
Gomme, Arnold W. A Historical Commentary on Thucydides. Volume I: Introduction and Commentary on Book I. Oxford: Clarendon Press, 1956.

Grainger, John D. Hellenistic Phoenicia. Oxford: Clarendon Press, 1991.

Green, Peter. The Greco-Persian Wars. Berkeley: University of California Press, 1996.

Green, Peter. Diodorus Siculus, Books 11-12.37.1: Greek History, 480-431 B.C. - The Alternative Version. Austin: University of Texas Press, 2006.

Güney, Hale. "Poseidon as a God of Earthquake in Roman Asia Minor", Revue Numismatique, vol. 172, 2015, p. 293-315.

Hammond, Nicholas G. A History of Greece to 322 B.C.. Oxford: Clarendon Press, 1967a.

Hammond, Nicholas G. "The Origins and the Nature of the Athenian Alliance of 478/7 B.C.", Journal of Hellenic Studies, vol. 87, 1967b, p. 41-61.

Hammond, Nicholas G. "The Expedition of Xerxes", The Cambridge Ancient History, Cambridge: Cambridge University Press, 1988, p. 518-591.

Harris, George. Ionia under Persia. A Political History. Doctoral Dissertation presented at the Northwestern University, 1971.

Heinrichs, Johannes. Ionien nach Salamis: die kleinasiatischen Griechen in der Politik und politischen Reflexion des Mutterlands. Bonn: R. Habelt, 1989.

Hignett, Charles. Xerxes' Invasion of Greece. Oxford: Clarendon Press, 1963.

Irwin, Elizabeth. "Herodotus and Samos: Personal or Political?", Classical World, vol. $102.4,2009$, p. 395-416.

Isambert, Émile. Itinéraire descriptif, historique et archéologique de l'Orient. Première partie: Grèce et Turquie d'Europe. Paris: Hachette et cie., 1873.

Joannès, Francis. "Conquérir l'Égypte grâce à la Babylonie. Réflexions sur la chronologie du règne de Cambyse en Babylonie", Achemenet. Vingt ans après. Études offertes à Pierre Briant à l'occasion des vingt ans du Programme Achemenet, edited by Damien Agut-Labordère, Rémy Boucharlat, Francis Joannès, Amélie Kuhrt and Matthew W. Stolper, Leuven: Peeters, 2021, p. 201-216.

Kagan, Donald. The Outbreak of the Peloponnesian War. London: Cornell University Press, 1969.

Kleber, Kristin. "Famine in Babylonia: A Microhistorical Approach to an Agricultural Crisis in 528-526 BC", Zeitschrift für Assyriologie, vol. 102, 2012, p. 219-244.

Klein, Alexis. Pharnabaze et les Pharnacides: une dynastie de satrapes sur les rives de la Propontide ( $V^{e}-I V^{e}$ siècle av. J.-C.). Doctoral Dissertation presented at the University of Strasbourg, 2015.

Lazenby, John F. The Defence of Greece, 490-479 BC. Warminster: Aris \& Phillips, 1993.

Lenfant, Dominique. Les Perses vus par les Grecs. Paris: Armand Collin, 2011.

Macan, Reginald W. Herodotus: The Seventh, Eighth, and Ninth Books. London: MacMillan and Co., 1908.

Maffre, Fréderic. "Cyzique et le monde achéménide", Cyzique, cité majeure et méconnue de la Propontide antique, edited by Patrice Schlosser and Michel Sève, Metz: Centre de Recherche - Universitaire Lorrain d'Histoire, 2014, p. 63-100.

Manoledakis, Manolis. "Misplacing Ancient Rivers in Modern Cartography and Literature: The Cases of Chabrias and Olynthiacus", Orbis Terrarum, vol. 13, 2015, p. 124-154.

Mathes-Schmidt, Margret, Pallikarakis, Aggelos, Papanikolaou, Ioannis and Reicherter, Klaus. "Event Deposits in the Eastern Thermaikos Gulf and Kassandra Peninsula (Northern Greece): Evidence of the 479 BC «Herodotus Tsunami»" Zeitschrift für Geomorphologie. Supplementband, vol. 62.2, 2019, p. 101-125.

Meiggs, Russell. The Athenian Empire. Oxford: Clarendon Press, 1972.

Mitchell, B. "Cyrene and Persia", Journal of Hellenic Studies, vol. 86, 1966, p. 99-113.

Müller, Dietram. Topographischer Bildkommentar zu den Historien Herodots: Griechenland. Tübingen: Ernst Wasmuth Verlag, 1987. 
Munro, Hugh A. "Xerxes' Invasion of Greece”, The Cambridge Ancient History, Cambridge: Cambridge University Press, 1953, p. 268-316.

Olmstead, Albert T. History of the Persian Empire. Chicago: University of Chicago Press, 1948.

Pelling, Christopher. "Herodotus and Samos", Bulletin of the Institute of Classical Studies, vol. 54.1, 2011, p. 1-18.

Psoma, Sélène. "Les Bottiéens de Thrace aux $\mathrm{V}^{\mathrm{e}}$ et $\mathrm{IV}^{\mathrm{e}}$ siècles av. J.-C.", Revue Numismatique, vol. 154, 1999, p. 41-55.

Rodríguez-López, Maria I. "Iconography of Poseidon in Greek Coinage", Greek Art in Motion: Studies in Honour of Sir John Boardman on the Occasion of his $90^{\text {th }}$ birthday, edited by Daniela Ferreira, Delfim Leão, Rui Morais and Diana Rodríguez-Perez, Oxford: Archaeopress Publishing LTD., 2019, p. 264-275.

Rung, Eduard. "The End of the Lydian Kingdom and the Lydians after Croesus", Political Memory in and after the Persian Empire, edited by Jason M. Silvermann and Caroline Waerzeggers, Atlanta: Society of Biblical Press, 2015, p. 7-26.

Sealey, Raphael. "The Origin of the Delian League", Ancient Society and Institutions: Studies Presented to Victor Ehrenberg on his $75^{\text {th }}$ Birthday, edited by Ernst Badian, Oxford: Blackwell, 1966, p. 233-255.

Shahbazi, Alireza Sh. "Darius in Scythia and Scythians in Persepolis", Archäologische Mitteilungen aus Iran, vol. 15, 1982, p. 189-235.

Smid, T. "Tsunamis in Greek Literature", Greece \& Rome, vol. 17.1, 1970, p. 100-104.

Stefanakis, Manolis I. "Natural Catastrophes in the Greek and Roman World: Loss or Gain? Four Cases of Seaquake-generated Tsunamis", Mediterranean Archaeology and Archaeometry, vol. 6.2, 2006, p. 5-22.

Vasilev, Miroslav. The Policy of Darius and Xerxes towards Thrace and Macedonia. Leiden: Brill, 2015.

Vasilev, Miroslav. "The Date of Herodotus' Visit to Macedonia", Ancient West and East, vol. 15, 2016, p. 31-52.

Wallinga, Herman T. "The Ancient Persian Navy and its Predecessors", Achaemenid History I: Sources, Structures and Synthesis. Proceedings of the Groningen 1983 Achaemenid History Workshop, edited by Helen Sancisi-Weerdenburg, Leiden: Nederlands Instituut voor het Nabije Oosten, 1987, p. 47-77.

Wiesehöfer, Josef. "Fourth Century Revolts against Persia: The Test Case of Sidon", Brill's Companion to Insurgency and Terrorism in the Ancient Mediterranean, edited by Lee L. Brice and Timothy Howe, Leiden: Brill, 2016, p. 93-112.

Will, Édouard. "Notes sur les régimes politiques de Samos au V $\mathrm{V}^{\mathrm{e}}$ siècle", Revue des Études Anciennes, vol. 71.3/4, 1969, p. 305-319. 
